\title{
PLAGUE IN ELIZABETHAN AND STUART LONDON: THE DUTCH RESPONSE
}

\author{
by
}

\section{OLE PETER GRELL *}

Plague was, without doubt, the most devastating disease that could hit an urban community in the early modern period. It was a regular visitor to London for three centuries from the Black Death of 1348 until its last outbreak in 1665. Its most terrifying impact was obviously felt when major epidemics occurred in the City-as they did in $1563,1593,1603,1625,1636$, and finally in 1665 . Nearly a quarter of London's inhabitants died in 1563 and more than 80,000 in the last epidemic in the metropolis in 1665-almost 20 per cent of the City's population. Apart from these major outbreaks, plague persisted in London during most of the intervening years in a milder, more endemic form. Between 1563 and 1665 - the first period for which we have reasonable data, thanks to the Bills of Mortality, it was only absent from the City from 1616 to 1624 and again from 1650 to $1664 .^{1}$

I will concern myself with the social response to plague within the Dutch community in London, whose provision for and care of infected members has been held up as "an example of foreign civility close to home" by Paul Slack in his recent study on the impact of plague in Tudor and Stuart England. I hope not only to expand this verdict, but also to modify it substantially. Accordingly, I shall attempt to demonstrate how and why this exceptional system, introduced by the London Dutch church during the plague of 1563, for the care and relief of plague-ridden members, was allowed to decay under the early Stuarts. Likewise, I shall try to show how this collapse of solidarity among the Dutch in London was accompanied, if not directly caused, by a gradual decline in religious commitment, i.e. secularization, loss of Dutch identity, and growing anglicization; and where possible compare it with the changing response of their English hosts. However, before taking a closer look at the Dutch community, it will be useful to make a brief assessment of the impact of, and the reactions to, the disease within the metropolis.

\footnotetext{
* Dr Ole Peter Grell, Wellcome Trust Fellow, University of Cambridge, Wellcome Unit for the History of Medicine, Free School Lane, Cambridge CB2 3RH.

I should like to thank Professor M. J. van Lieburg, Professor J. van den Berg, Dr P. Hoftijzer, Dr A. Cunningham, and an anonymous referee for their comments and kind suggestions.

${ }^{1}$ See F. P. Wilson, The plague in Shakespeare's London, Oxford, Clarendon Press, 1927; W. G. Bell, The Great Plague in London 1665, London, Bodley Head, 1951; P. Slack, 'Metropolitan government in crisis: the response to plague', in London 1500-1700. The making of the metropolis, ed. A. L. Beier and R. Finlay,
} 


\section{The Dutch response to plague in London}

Plague struck in fearful concentration. Most of the major epidemics appear to have run their course within a few months. In 1625, for instance, plague did not break out until the beginning of June and was petering out by November, having killed over 20,000 people out of a population of more than 200,000 . Thus more than a tenth of London's population perished in less than six months - small wonder that local, as well as, central, government found itself under tremendous pressure in times of plague. Paul Slack has demonstrated how outbreaks of plague gradually became more concentrated in London, both topographically and socially, during the early Stuart period. The reason for this change is to be found in London's colossal growth in the previous century, from around 85,000 in 1563 to 459,000 in 1665 . This happened in spite of more than a sixth of the population being killed by plague at irregular intervals. It must have been a staggering task for the Lord Mayor and Alderman just to keep the City going under normal conditions, not to mention during the havoc wrought by major epidemics.

The population explosion led to overcrowding and bad health among the poor, who could only afford to live in the most dilapidated tenements as pressure on the housing market grew. During the plague of 1563 there was hardly any difference in mortality between the different parishes in the City. By 1665 the mortality rates in the poorer parishes and suburbs to the south and north-east of the City were double those in the centre. In the early seventeenth century, plague began to show a clearer social bias, as the poor found themselves squeezed together in sheds, cellars, and subdivided tenements on the outskirts of London. A contributive factor to the improved mortality rate of the richer, central parishes during the early Stuart period should also be sought in the growing tendency among the richer citizens to flee the City. ${ }^{2}$

England was much slower than most European countries in introducing public precautions and regulations against plague. Not until 1518 had the first tentative steps been taken towards marking infected households. But the country had to wait until 1578 before it received its first plague orders and London did not receive any regulations until May 1583. Issued by the Privy Council, the plague orders are evidence of government intent rather than expressions of practical policy. Most of the regulations, such as certification of deaths, appointment of searchers and watchmen, control of times of burial, and the fundamental policy of household segregation, were similar to those already in force in a number of Continental cities. In two respects the English regulations differed from their Continental prototypes: they introduced taxation to support the sick, and the isolation of the infected was unusually strict. This strictness was reinforced in 1604 , when the government provided penal sanctions to support the policy of isolation. Watchmen were given the right to use force to keep people shut up, and anyone with plague sores found wandering outside their homes in the company of others might be hanged. Alongside the penal measures were more positive attempts to provide for care: the orders of 1583 provided for a number of plague-officers in each parish and when they were revised in 1609 , they also included

London, Longman, 1986, pp. 60-81, and P. Slack, The impact of plague in Tudor and Stuart England, London, Routledge \& Kegan Paul, 1985, especially pp. 144-72.

${ }^{2}$ For the example of the Dutch community, see ibid., pp. 205-6; see especially pp. 153 and 166 for changes in the patterns of disease. 


\section{Ole Peter Grell}

orders for the appointment of six surgeons who should supervise medical aid in the City. The 1609 edition of the plague orders was reprinted without major alterations in 1630,1646 , and 1665 .

The implementation of the orders, however, left much to be desired. It turned out to be difficult to recruit people for the jobs of searchers, nurses, watchmen, etc. in most parishes. The financial limitations of several parishes which made the employment of extra personnel difficult; only few candidates could be found for such dangerous jobs; and those who did come forward were often unreliable. What parish relief there was tended to break down in the greater epidemics. During the plague of 1625 the London Aldermen initially allowed one member of each infected household to go out for provisions, but by the middle of August, even this "softer" approach to segregation had broken down totally-a development that repeated itself in $1665^{3}$

In spite of these shortcomings, the responses to the crises from the Lord Mayor and Aldermen and the Privy Council eventually bore some fruit. A pesthouse was started in St Giles Cripplegate in 1594, although it was far from sufficient for a city the size of London. Small and unfinished as it may have been in 1603 -only 135 people are listed as having died there while the outbreak peaked from the beginning of July until the end of December-the London-based Dutch merchant and writer, Jacob Cool, nevertheless considered it extremely useful for the City during the plague in 1603. Cool, an eye-witness who remained in London throughout the plague, informs us that carts drove through the City at midnight to collect the sick and bring them to the pesthouse. It would appear, however, that this service was primarily for the benefit of the poor or used by masters and householders who forced their sick and often unwilling servants into the carts. 4

By the end of the sixteenth century a number of parishes had begun to employ at least a couple of searchers and nurses. Segregation of infected households was attempted in most parishes from 1625 onwards and only appears to have folded completely in the midst of major outbreaks. Not until the epidemic of 1636 , however, were extra taxes collected in London, even if the City had benefited from a national collection in 1625, ordered by Parliament while it met in Oxford. During the outbreak of 1625 the City fathers employed for the first time two doctors to look after plague victims, and they paid out nearly $£ 300$ in medical expenses. Admittedly, the responses to plague were slow in materializing in the metropolis and when adopted were often less than efficient, but the Stuart period especially bears witness to a gradual, albeit modest, improvement in the attempts to control and regulate the epidemics. ${ }^{5}$

The efforts of the Dutch congregation in London certainly outstripped those of its English host community during the plague of 1563. Apart from marking infected houses and some attempts by the Lord Mayor and Aldermen towards segregation of

\footnotetext{
${ }^{3}$ Ibid., pp. 202 ff., 213-23; see also Slack, 'Metropolitan government', op. cit., note 1 above.

${ }^{4}$ See Jacob Cool, Den Staet van London in hare Groote Peste, ed. J. A. van Dorsten and K. Schaap, Leiden, E. J. Brill, 1962, p. 32. For Jacob Cool, see also J. A. van Dorsten, “"I.C.O.”: the rediscovery of a modest Dutchman in London', in The Anglo-Dutch renaissance. Seven essays, Leiden, E. J. Brill, 1988, pp. 8-20.

${ }^{5}$ Slack, 'Metropolitan government', op. cit., note 1 above, pp. 65-72. For the attempts to control epidemics in London during the 1630 s and the co-operation between the College of Physicians and the Privy Council, see Harold J. Cook, 'Policing the health of London: the College of Physicians and the early Stuart monarchy', Soc. Hist. Med., 1989, 2: 1-33.
} 


\section{The Dutch response to plague in London}

infected households, very little was achieved by local government in London. By contrast, the Dutch church in Austin Friars, which then had around 1,600 members spread around the City, took immediate action when the epidemic started to accelerate in July. The consistory decided to employ one surgeon and secure the services of another, if need arose, to look after the poorer members of the community in particular. The surgeon was given a lump sum of 16 shillings and promised a salary of five shillings a week for looking after the poor. The elders used the opportunity to stipulate who was included under this heading: only those who received alms from the congregation! The richer members were expected to pay the surgeon for his services. Names were also taken down by the consistory of members who were willing to serve as watchers and nurses. A few days later, the community appointed two deacons as visitors of the sick to assist the ministers in attending the infected. ${ }^{6}$ The visitors were charged with appointing watchers and nurses, helping the sick in drawing up their wills, and providing consolation and admonition. They were expected to cover both the spiritual and medical domains, but a clear emphasis was placed on pastoral care. Like the surgeon, they were offered a respectable salary. The Dutch consistory was careful when employing people to look after its plague victims. Thus rumours to the effect that the Walloon-French community's surgeon was attending the sick in the company of a whore, made the ministers and elders of Austin Friars refuse to recommend him to their members.

The Dutch community in London may well have taken the lead among the Dutch Reformed churches in exile, as well as in The Netherlands, by creating these positions. They should be seen as an early example of community medicine with their emphasis on care and consolation for the sick. M. J. van Lieburg has indicated that the visitors of the sick employed by the Reformed Church in Rotterdam in the early seventeenth century paid increasing attention to the medical aspects of their job during epidemics. Whether or not that was true for the visitors in Austin Friars by the turn of the century remains an open question. ${ }^{7}$

Originally Austin Friars appears to have intended to inform its members of the Lord Mayor's order for the isolation of infected households-allowing only one member per household out for provisions. Then they changed their minds and struck out the order previously entered in the minutes of the consistory. Evidently, it did not fit the community's policy of allowing healthy members from infected households to attend service in Austin Friars together with those who were involved in looking after the sick. The church took the precaution, however, of requesting these members to sit separately in the church in order not to worry the "weaker brethren" and "pregnant

\footnotetext{
${ }^{6}$ See A. Pettegree, Foreign Protestant communities in sixteenth century London, Oxford University Press, 1986, pp. 207-8; see also Slack, Impact of plague, op. cit., note 1 above, p. 272. The minutes of the Dutch church from 1563 would indicate that the two visitors of the sick were employed to assist ministers in their house visits, not to replace them, as suggested by Pettegree and Slack: see Kerkeraads-Protocollen der Nederduitsche Vluchtelingen-Kerk te London 1560-1563, ed. A. A. van Schelven, Amsterdam, Johannes Müller, 1921, pp. 432-3, henceforth Kerkeraads-Protocollen.

${ }^{7}$ Kerkeraads-Protocollen, p. 434. For the example of Rotterdam, see M. J. van Lieburg, 'Geneeskundige zorg als kerkelijke taak. De situatie in de gereformeerde kerk van Rotterdam in de zeventiende eeuw', in De Zeventiende eeuw, 1989, 5(1): 162-71, especially p. 165. For visitors of the sick in general in The Netherlands, see the forthcoming book by F. A. van Lieburg and M. J. van Lieburg, De ziekentrooster in de gereformeerde kerk tijdens de Republiek. Een studie over de pastorale geneeskunde te Rotterdam.
} 


\section{Ole Peter Grell}

sisters". Likewise, those members who had recovered from the disease were requested to be certified as healthy by the surgeon or "such people who have experience of plague" before they started to attend service. The community also demonstrated its enlightened attitude by debating whether or not plague was contagious, but in spite of the debate being "intelligently conducted", it appears to have caused considerable anxiety among the less well-educated members. ${ }^{8}$

The three-tiered structure of the Dutch community, comprising ministers, elders, and deacons, held up well in this crisis. Consistory meetings continued throughout the summer and, while the infection spread, the officers of the community did their best to tackle the effects of the disease. There was, however, a price to be paid for this unlimited solidarity within the community-the two most senior ministers died within a couple of days of each other in September and the church's finances were in disarray well into the $1570 \mathrm{~s}^{9}$

In noting the vigour of this collective action, however, we should not forget that the epidemic of 1563 happened only three years after the Dutch community had been re-founded under Elizabeth after years of exile during the reign of Mary. Obviously a strong sense of community and solidarity prevailed within the congregation. The church was still in its apostolic age, regularly sending ministers and elders to The Netherlands to assist "the churches under the cross", and its officers were highly committed Protestants rooted in the Second Reformation. The community was, in other words, extremely well equipped to tackle this crisis. ${ }^{10}$

No records covering the community's response to the plague in 1593 have survived. Only the minister Simon Ruytinck's short note in his History confirms that the epidemic in 1593 was less serious than in 1563, stating that "because the Godly humbled themselves before the Lord his punishing hand was removed". "Ten years later, in 1603, London was faced with another serious outbreak of plague. This outbreak took a severe toll among the Dutch community. We can safely assume that the mortality rate among the Dutch was at least as high as among the English, which would mean that around one-fifth of the community died. Simon Ruytinck, who served Austin Friars as a minister from 1601 to 1621 , wrote that 370 Dutch households were affected by the plague and that some 670 people died. Once more the community lost a minister in the epidemic. Assuerus Regemorter, the most experienced of the church's three ministers, died in September. With nearly threequarters of all the congregation's households infected, it is not surprising that the ministers were exposed. ${ }^{12}$ The gap in the minutes of the consistory, due to the loss of a consistory book, makes it difficult to assess what measures the community introduced in 1603 .

\footnotetext{
${ }^{8}$ Kerkeraads-Protocollen, pp. 435-6. See also Gheschiedenissen ende Handelingen die voornemelick aengaen de Nederduytsche Natie ende Gemeynten wonende in Engeland ende in bysonder tot London, ed. J. J. van Toorenenbergen, Werken der Marnix-Vereeniging, Serie III-Deel I, Utrecht, Kemink \& Zoon, 1873 , p. 59, henceforth Gheschiedenissen.

${ }^{9}$ Pettegree, op. cit., note 6 above, pp. 208-9.

${ }^{10}$ See O. P. Grell, Dutch Calvinists in early Stuart London, Leiden, E. J. Brill, 1989, especially chapters 1 and 3 .

11 Gheschiedenissen, p. 154.

12 Grell, op. cit., note 10 above, p. 101, notes 198, 199.
} 


\section{The Dutch response to plague in London}

Fortunately, the already mentioned merchant-writer and later elder to Austin Friars, Jacob Cool, offers some assistance. In his narrative poem, Den Staet van London in hare Groote Peste (The State of London during the Great Plague), written in 1604, immediately after the plague had subsided, and published in Middelburg two years later, Cool informs us that "the brave Dutch shepherds and others did not fail to go in God's name to see those who wanted their assistance". The church also appointed two visitors of the sick "who without fear served under the ministers"; it was therefore the same arrangement and number of visitors as in 1563.

Jacob Cool, a self-taught classicist, a learned collector of Greek and Roman coins and medals, a herbalist, and above all, a staunch Calvinist, remained in London throughout the plague. He admitted to having been terrified, but his faith came to his assistance and stopped him from fleeing the City. This, however, did not lead him to rely passively on Providence. He took good care of himself in accordance with the advice of his physician, who might well have been another Dutch exile, Dr Baldwin Hamey, who had settled in London in 1598. Cool informs us that he "carried something in his hand and something in his mouth" when he ventured out, avoiding the sick and those who frequented infected houses. Evidently he believed in traditional remedies prescribed in times of plague and would have had angelica in his mouth and carried something to sniff while walking the streets. In spite of being scared, he felt that "reason and necessity" obliged him where possible to make himself useful to the afflicted. Cool's exemplary behaviour caused his friend, Johannes Radermacher, a former elder to Austin Friars then living in Middelburg, to write: "I must praise you for having faced the dangers of the plague rather than abandon your people and I have no doubt that God rewarded you by sparing your family and restoring your kinswoman to health". 13

Besides providing us with these glimpses of a rich and well-educated Dutchman's reaction to plague, Cool's poem also provides some interesting observations about the social conditions in London during the epidemic of 1603, and in particular offers two important correctives to the accepted view of plague in London during this period. Firstly, he claimed that the longer the plague lasted in 1603, the more people's fear of it diminished. One of the consequences was that the increasing number of poor people who found themselves out of work made it much easier for the parishes to find enough "strong and brave people" to look after the sick, thus solving the difficulties of recruiting reliable nurses, watchmen and searchers. Secondly, Cool confirms the well-known fact that the impact of the 1603 outbreak was much graver in the suburbs than the inner City, because of overcrowding and the miserable housing conditions in those areas. But he adds another important reason for the high mortality in the suburbs. He pointed to the fact that several well-to-do citizens in London owned small "garden- or pleasure-houses" in these areas, where they chose to send members of

\footnotetext{
${ }^{13}$ See Cool, op. cit., note 4 above, pp. 31, 48-9. For Johannes Radermacher's letter, see Ecclesiae Londino-Batavae Archivum, ed. J. H. Hessels, 3 vols. in 4 parts, Cambridge University Press, 1889-97, vol. 1, no. 334, henceforth Hessels. The "Dr 'Anneus', the physician", whom Johannes Wouerius from Antwerp asked Cool to salute in November 1603, adding that he hoped that "they are all well and have survived the mortality", can only refer to Baldwin Hamey or Hameus, see Hessels, vol. 1, no. 332. Dr Hamey stayed in London throughout the plague of 1603 and again in 1625: see J. J. Keevil, Hamey the stranger, London, Geoffrey Bles, 1952, pp. 95, 142-3.
} 


\section{Ole Peter Grell}

their households who caught the plague, thus adding to the number of suburban casualities. $^{14}$

The elders in London might well have gratefully accepted the suggestion of the Dutch congregation in Sandwich:

As we hear that the Lord Chastises London with the plague against which there is no better remedy than praying and a sincere repentance, combined with means granted by him, as skilful Doctors, one of our brethren, a devout man, who has faithfully served us formerly as pestemeester in times of epidemic, offers you his services now. ${ }^{\text {is }}$

This statement, together with Jacob Cool's reaction, demonstrates the practical and activist attitude to plague which prevailed among the Dutch churches in England. That God was seen as chastising the communities with this terrible disease did not lead to its passive reception. The strong, Counter-Remonstrant Calvinism of the Anglo-Dutch congregations, with its emphasis on Providence, did not generate anything akin to apathy; rather, in accordance with Calvin's Institutes, it guaranteed that the churches considered it part of their Christian obligation to try to preserve human life, through the means God had placed at their disposal, i.e., care and medical remedies. And the advice from the church in Sandwich echoes the writings of such leading hardline Zeeland Calvinists or Pietists as Willem Teellinck, a friend and correspondent of Jacob Cool, and Godfrid Udemans. Teellinck's argument in his pamphlet Zion's Trumpet, for the medical treatment of plague victims, as being "part of God's advice which we must follow", provided the theological rationale for the Sandwich congregation's letter. ${ }^{16}$

Some form of self-imposed household isolation appears to have become standard practice among the Dutch in London at the time of James I's accession, assuming that the example of Hadrianus Damman, the Ambassador of the States General to Scotland, who had accompanied James to England in 1603, is typical. Writing to the consistory of Austin Friars from Edinburgh in January 1605, Damman apologized for not having thanked the consistory in person before returning to Scotland. His son-in-law and niece had died from the plague in the house he had rented in London after the whole family had taken communion in Austin Friars. He and his wife had then returned to Edinburgh "after having patiently waited for a month for the Lord in prayers". 17

${ }^{14}$ See Cool, op. cit., note 4 above, pp. 31, 33.

${ }^{15}$ Hessels, vol. 3, no. 1575.

${ }^{16}$ For Willem Teelinck and Godfrid Udemans, see M. J. van Lieburg, 'Zeeuwse Piëtisten en de Geneeskunde in de eerste helft van de 17e eeuw', in Worstelende Wetenschap. Aspecten van wetenschapsbeoefening in Zeeland van de zestiende tot de negentiende eeuw, Archief, Medelingen van het Koninklijk Zeeuwsch Genootschap der Wetenschappen, Middelburg, 1987, pp. 63-86. The opposite view of orthodox Calvinism, as encouraging passivity and apathy, has recently been argued rather unconvincingly by L. Noordegraaf and G. Valk, De Gave Gods. De Pest in Holland vanaf de late Middeleeuwen, Bergen, Octavo, 1988, especially pp. 124-31. For Zion's Trumpet, see W. Teellinck, Zions Basayne. Aenstecken uit de woorden van Psalm 7: 13 en 14., Middelburg, 1621. Jacob Cool and Willem Teellinck not only corresponded and exchanged books, Teellinck also dedicated one of his books to Cool (Sleutel der Devotie, Amsterdam, 1624): see Documentieblad Nadere Reformatie, 1989, 13(1), pp. 3-4; and Hessels, vol. 1, no. 371.

${ }^{17}$ See Hessels, vol. 3, no. 1640; for Hadrianus Damman, see Nieuw Nederlandsch Biografisch Woordenboek. 


\section{The Dutch response to plague in London}

With or without assistance from the former Pestemeester from Sandwich, the visitor of the sick, Francoys vanden Broecke, managed to get through the epidemic of 1603. He is included in the earliest list of salaried personnel in the church from 1606. The experience in 1603 had probably convinced the leadership in Austin Friars of the need to employ him on a permanent basis. Being a married man without offspring, he was well-suited for the job. He was a silk weaver by training, but unlike his predecessors in 1563, he was never considered for a deaconship-his humble position as a craftsman would probably have excluded him, since by the end of the sixteenth century elders and deacons were almost all recruited from among the merchants, the upper social category within the congregation. Vanden Broecke's normal salary as visitor of the sick was $£ 8$ p.a., but during periods of plague he received extra payments from the church. In 1608 the consistory offered him a gift of $£ 3$ for his efforts on behalf of plague-stricken members, and from 1612 Vanden Broecke combined his position as visitor with that of Voorleser ("Reader") and consequently received a higher salary of $£ 12$ p.a. ${ }^{18}$

Not until London was hit by another surge of infection in 1625 does a more detailed picture of how Austin Friars responded to epidemics in the early seventeenth century materialize. By now the original, committed front-line efforts of several of the church's ministers and deacons appear to have been replaced by those of lowerranking officials like Francoys vanden Broecke. The consistory, in fact, went a step further in 1625. The ministers and elders decided in June that Vanden Broecke should be spared from visiting those members who had caught the plague. Instead the community wanted to hire a temporary visitor of the plague-stricken to look after the growing number of victims. The attempt to employ a certain Steven Schier failed and the consistory found it necessary to request Vanden Broecke to look after infected members for another three or four weeks until an extraordinary visitor of the sick could be appointed. A consistory meeting on 10 July decided to employ Jan Schram as a temporary siecken-trooster. He was given a lump sum of 15 shillings, and promised nine shillings a week for looking after plague-stricken members. Schram was only employed after a thorough examination by consistory members. He was a silk weaver like his colleague, but was considerably younger than Vanden Broecke, and the father of at least four children. He was also substantially poorer. Unlike Vanden Broecke, who lived in Duke's Place within the walls of the City and whose moderated rent was assessed to $£ 5$ in 1638, Schram lived in Southwark and was listed under the category of members of Austin Friars who in 1617 were described as "householders the most part very poor". 19

Our brother, Joos Godschalck, has informed us that he has talked to the wife of Jan Schram asking her firstly whether she consented to her husband occupying the position of extraordinary visitor of the sick; to this she replied in all frankness that she

\footnotetext{
18 Guildhall Library MS 7390/1, ff. 12, 27.

19 Returns of aliens dwelling in the City and suburbs of London, ed. R. E. G. and E. F. Kirk, Huguenot Society Publications 10, 4 vols., London 1900-08. For Jan Schram, see vol. 3, pp. 142, 157, 168. For Francoys vanden Broecke, see ibid., pp. 142, 156, 175; and Returns of strangers in the metropolis 1593, 1627, 1635, 1639, ed. I. Scouloudi, Huguenot Society Publications 57, London 1985, p. 345, no. 2666.
} 


\section{Ole Peter Grell}

had prayed to the Lord, together with her husband, for this to happen and that she approved. Secondly, our brother Godschalck asked her whether her husband had not left her for a period going abroad without her knowledge or consent. In denying this she swore fervently and added that those who claimed this did her and her husband great injustice. Jan Schram appeared before the brethren after certain brethren had negotiated with him; he was informed that according to his request we would now call and employ him as a visitor of the sick in these difficult times; and that the brethren once and for all, would make him a present of fifteen shillings and promised to pay him nine shillings a week as long as the plague may last; and when we do not need his services any longer he will be given two months notice (by the time the Lord decides to remove his punishing hand from us). He accepted this and accordingly counted his fifteen shillings in our presence. ${ }^{20}$

The consistory took great pains in making sure that Jan Schram's marital and domestic situation was in reasonably good order and that his wife consented to his employment in an obviously risky job. The ministers and elders had to assure themselves that no serious doubt could be raised about his moral integrity. After all, Schram was to be entrusted with the life and property of members who were seriously ill and dying, helping them in drawing up their wills. Any irregularities in this respect would reflect badly on the consistory members, who were ultimately responsible.

Dealing with the casualties of the plague was only part of the duties of the ministers and elders during epidemics. They also had to calm and console those members who were not infected, but who lived in constant fear of contracting the disease. In July members were told that services in Austin Friars would be continued on Sundays as well as weekdays. A month later some members complained to the consistory that they were anxious about people appearing in church "with open sores". The consistory decided to request these people, obviously convalescing from plague, either to stay away from the services, or if they insisted on attending, to remain segregated from the rest of the community in a separate section of the church. ${ }^{21}$ This decision was not totally dissimilar to the one reached by their predecessors in 1563 , despite the fact that by 1625 considerations for the healthy appear to have taken precedence over care for those who had been struck by the disease.

The Dutch congregation probably suffered as much as the English parishes during the outbreak of 1625 , but this time, at least, it lost none of its ministers. The ministers and elders appear to have fulfilled their obligations towards the church and the weekly consistory meetings continued throughout the crisis, except for a couple of interruptions in September. By December the infection was on the wane and the consistory decided it was time to discharge its extraordinary visitor of the sick, Jan Schram. On top of his salary, Schram was given a gift of $£ 2$ for his services to the community, while the permanent visitor, Francoys vanden Broecke, was awarded $£ 10$ for his efforts during the plague. Vanden Broecke and Schram's salaries and awards were generous compared with what the City fathers paid their employees. The keeper of the pesthouse in St Giles Cripplegate received $£ 5$ p.a. in 1612 and during the plague of 1625 the resident surgeon in the pesthouse was given a salary of $£ 30$; both these gentlemen were offered a gift of $£ 5$ as a "reward for their care and pain".

${ }^{20}$ Guildhall Library MS 7397/7, f. 127r.

21 Ibid., f. 127v. 


\section{The Dutch response to plague in London}

Francoys vanden Broecke retired five years later, in January 1630, having served the community as its sick-visitor for more than a quarter of a century. His retirement, however, turned out to be brief. In July he agreed to look after plague-stricken members of the community for half a year, for which he was paid a salary of $£ 6 .{ }^{22}$ But an era had come to an end within Austin Friars and the church had begun to retrench in earnest on its social commitments. The congregation was never again to employ a permanent visitor of the sick. Some attempts were made to reintroduce the position in 1641, but eventually the consistory only employed Jan Schram for 2 years at $£ 10$ p.a.- "if God gives him health to perform this duty", as one of the ministers added in the minutes. It was specified on this occasion that, under ordinary conditions, Schram was obliged to look after all the community's sick, but in times of plague he should concentrate on the infected. ${ }^{23}$

Thus, when another major epidemic hit London in 1636, the congregation in Austin Friars was as unprepared as it had been back in 1563, while it had to face the new outbreak at a time when the original sense of community and solidarity within the church was disappearing. The church decided to re-employ its former extraordinary siecken-trooster, Jan Schram, in early May, but at a considerably lower salary than in 1625 - three shillings a week, as opposed to the nine shillings he had received originally. Neither was Schram offered any terms of notice in 1636; instead the minutes simply stated that "he will be bound to us but we not to him". This meaner attitude on the part of the church's leadership coincided with its efforts to bring Austin Friars' alms expenditure under control, while the new Archbishop William Laud's drive for religious uniformity from 1634 can only have caused the ministers and elders to show great care in their financial administration. ${ }^{24}$

By 1636 the Privy Council and the Lord Mayor and Aldermen sought to enforce household segregation more rigorously than before. The consistory in Austin Friars must have received information about the stricter policies, since in May it discussed how far and where the temporary visitor of the sick, Jan Schram, would be allowed to go during the plague. It was decided to contact the French consistory to learn what information it might have received from the Lord Mayor and Aldermen. At the following week's consistory meeting in Austin Friars, the ministers and elders were of the opinion that in future they should be in touch with Schram before he went to see new plague-casualties within the community. ${ }^{25}$ The activities of the visitors from the Dutch and French churches did not go unnoticed by the English authorities. On 7 June the Privy Council enjoined the Lord Mayor to stop the visitors of the Dutch and Walloon-French congregations from criss-crossing the City and moving freely

\footnotetext{
22 Ibid., ff. 130r, 217r, 222r; see also Scouloudi (ed.), op. cit., note 19 above, p. 345, no. 2666. Vanden Broecke appears to have returned to taffeta-weaving in 1635 when he was well over 60 . He left $£ 100$ at 6 per cent p.a. in the hands of the consistory of Austin Friars, when he finally retired. See O. P. Grell, 'From uniformity to tolerance: the effects on the Dutch church in London of reverse patterns in English church policy from 1634 to 1647', Nederlands Archief voor Kerkgeschiedenis, 1986, 66, p. 31. For the salaries paid employees of the City, see Wilson, op. cit., note 1 above, p. 83.

23 Guildhall Library MS 7397/7, f. 103v.

${ }^{24}$ Guildhall Library MS 7397/8, f. 42v. See also Grell, op. cit., note 10 above, pp. 94-104.

25 Ibid.
} 


\section{Ole Peter Grell}

between the infected and the healthy, and to guarantee the maintenance of household segregation among the foreign communities. The Lord Mayor was ordered,

to send to the French and Dutch churches to charge them to take order that the houses of such of their congregations as are infected be presently shut up, that there be no such visits made where the plague is, and if they will not forbear, he is to take care that such consolators be shut up in the houses infected. ${ }^{26}$

If this order was passed on to the Dutch church, the ministers and elders chose to ignore it. On 16 June the consistory decided that concerning the undertakings of the pest-siecken-trooster the church would act "in accordance with God". This was a clear indication that the leaders of the community had every intention to continue sending their visitor to assist members who caught the disease. In the spiritual field, however, the community joined hands with its hosts. It decided in October to obey the Royal Proclamation and institute a weekly day of fasting and praying on Wednesdays with two sermons, one in the morning and one in the afternoon, at the same time cancelling its normal services on Tuesdays and Thursdays. ${ }^{27}$

While the number of casualties grew during the summer and the pressure on the church's finances increased, the ministers, and most of the elders and deacons, continued to honour their responsibilities. The consistory met regularly throughout 1636, often together with the deacons, to deal with matters small and great. The schoolmaster, Abraham de Cerf, whose school recruited most of its pupils from the congregation, informed the church in July that the plague had brought a halt to his activities. Evidently, most of his fee-paying pupils had stopped attending his school because of fear of infection, well in advance of the City-fathers' decision to close all schools. De Cerf was recommended to the charity of the deacons. His predicament, however, is the first indication in the minutes of the church that the richer members of the community, like their English counterparts, had started taking to their heels, leaving London for the safety of the countryside. ${ }^{28}$ That this was the case is confirmed by the minutes from October and November, when the three officers decided that a special collection was needed within the community in order to reinstate the poor-box after its colossal outlay over the summer for the plague-stricken. After a lengthy debate in October, the ministers and those elders and deacons who had not fled the City decided to write to their absent colleagues, requesting them to attend the following weeek's consistory meeting. Their presence was needed in order to determine whether or not it was advisable to start a general collection for the poor "at this time of the plague when the wealthier members have taken up their residences in

\footnotetext{
${ }^{26}$ C.S.P. Dom Charles I, vol. 325, no. 69. The Dutch and Walloon churches in Norwich also employed visitors of the sick during outbreaks of plague in the early seventeenth century, but their activities appear to have been strictly controlled by the magistracy. They were ordered to retire from company, and not to go out after "candle lighting except on absolute necessity and always to carry a red wand a yard and a half long, their wives and family also to do the same"'. See W. J. C. Moens, The Walloons and their Church at Norwich, Lymington, 1887/8, p. 82.

${ }_{27}$ Guildhall Library MS 7397/8, ff. 45r, 45v, 46r. It would appear that the Dutch community shared its opposition to these public health measures with English Puritans: see Slack, Impact of plague, op. cit., note 1 above, p. 231.

${ }^{28}$ Guildhall Library MS 7397/8, ff. 45r, 45v, 46r; and Wilson, op. cit., note 1 above, pp. 94, $100,134$.
} 
the countryside". Accordingly, the next consistory meeting took the decision to launch a collection: "The members who are residing in the country this summer because of the plague or for other reasons, should receive letters if they are not able to appear in person, in order that they may write and inform us of their benevolence". ${ }^{29}$

The church's poor-box was in a lamentable state towards the end of 1636 . The crisis had seen expenditure soar from $£ 1,530$ the previous year to $£ 2,680$ in $1636-£ 925$ more than the deacons had managed to collect. During May and June the deacons had paid out more than $£ 700$, as opposed to between $£ 100$ and $£ 200$ under normal conditions. The general collection that took place from November to December netted the community an extra and much needed $£ 803$, which restored some balance

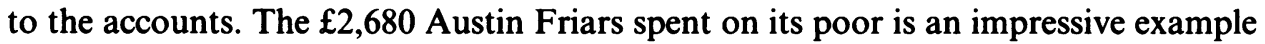
of Calvinist charity, especially when compared with the total of $£ 2,532$ that the City had spent on poor relief during the previous outbreak of plague in $1625 .^{30}$

The temporary pest-siecken-trooster, Jan Schram, remained in the church's employment until June 1638, when it was decided to pay him off since the plague "with God's assistance" had disappeared. Schram, who after two years' employment had hoped for the position to become permanent, was paid a salary until the end of the year in recognition of his services. ${ }^{31}$

We can conclude that the early Stuart period witnessed a gradual decline in the social care and commitment shown by the Dutch church during outbreaks of plague, compared with its efforts in 1563 . However, in spite of the decline, the church fared considerably better than most London parishes. In times of crisis the congregation could still rely on its ministers and a nucleus of committed elders and deacons to keep the community together and provide care for the afflicted, assisted by at least one pest-siecken-trooster.

After the epidemic of 1563, Austin Friars does not appear to have employed any physicians or surgeons during the following outbreaks of plague. We can, however, assume that the Leiden-educated, Anglo-Dutch poet and physician, Raphael Thorius, a member of the College of Physicians, who was a close friend of the minister to Austin Friars, Simon Ruytinck, attended infected members of the community during the epidemics of 1603 and 1625 . Thorius, who eventually died of the infection during the summer of 1625 , appears to have offered his services unflinchingly during outbreaks of plague, acting "more for the publick (by exposing his person too much) than his most dear concern". ${ }^{32}$ The services of Thorius, or for

\footnotetext{
${ }^{29}$ Guildhall Library MS 7397/8, f. 45r.

${ }^{30}$ For the London figures, see Wilson, op. cit., note 1 above, pp. 166-8. For Dutch community figures, see Grell, op. cit., note 10 above, chapter 2 , section 4.

31 Ibid., pp. 103-4.

32 A number of ministers in the Dutch Reformed churches in The Netherlands appear to have hesitated or even refused to visit plague-stricken members of their communities in the 1570s. The National Synod of Dort in 1574 emphasized ministers' obligation not to make any distinction between plague and other diseases, but to visit all sick members, at the same time underlining that ministers should not undertake any unnecessary risks. The Synod's decision is to say the least ambiguous, see Acta van de Nederlandsche Synoden der zestiende eeuw, ed. F. L. Rutgers, Werken der Marnix-Vereening, Serie II-Deel II, Utrecht, Kemink \& Zoon, 1889, p. 159; see also Noordegraf and Valk, op. cit., note 16 above, p. 124. The Synod of the Dutch and Walloon-French churches in England, which met in London in May 1644, emphasized that it was "the duty of a Minister at all convenient times to visit the sick, that are under his charge, when he is
} 


\section{Ole Peter Grell}

that matter other foreign doctors practising in London, such as the Royal physician, Theodore de Mayerne, Johannes Brovaert, and the Baldwin Hameys, Senior and Junior, would not have been restricted to the richer members of the church. That members of modest means, assisted by the deacons, were able to consult these gentlemen can be seen from the case of the Austin Friars's verger who in June 1649 was advised by Theodore de Mayerne to seek cure at a water resort. ${ }^{33}$

The earlier example of Raphael Thorius did not inspire those physicians who were members of the Dutch church at the time of the plague of 1665 . It would appear that Dr Johannes Rhegius, or John King, as he was known in the College of Physicians, had fled the City like many of his colleagues from the College. That would explain why the minister to Austin Friars, Philip Op de Beck, was able to consult him while "convalescing" in Barnes in September 1665, at a time when Dr King's expertise on fevers must have been badly needed in the City. ${ }^{34}$

In 1665-five years after the Restoration-the provisions offered by Austin Friars in times of plague saw a further decline. Now the church could not even manage to employ a temporary sick-visitor and its governing body, the consistory, appears for the first time in the community's existence to have been unable to cope with the crisis. It only mananged to meet twice while the infection peaked during the summer months, and there is no record of meetings between 15 June and 28 September. Those officers of the church who remained in the City and did their duty had great difficulty in convincing their less stalwart colleagues to return. The wealthy merchant and deacon to Austin Friars, Joas Evensen, was not tempted to obey the call of the minister, Jonas Proost, and return from Oxford. He excused himself with urgent business obligations and added:

On the 12th of October my partner's house was attacked by the plague, and one of our servants died while another died of it within three weeks, while my maid-servant, who remained with my servant in my house near Founder's Hall, was attacked by many ulcers in the beginning of November. My servants writes to me that she is now better, but I, who have been now for nearly three months in the open air, could not go at once to my house without great danger.

\footnotetext{
called thereunto", in spite of the claim of the Dutch representatives to the Synod that the ministers in the Netherlands were under no such obligation, see Acten van de Colloquia der Nederlandsche Gemeenten in Engeland 1575-1609. Aanhangsel. Uittreksels uit de Acten der volgende Colloquia 1627-1706, ed. J. J. van Toorenenbergen, Werken der Marnix-Vereening, Serie II-Deel I, Utrecht, Kemink \& Zoon, 1872, p. 333. For Thorius, see Anthony Wood, Athenae Oxonienses, ed. Philip Bliss, 4 vols., London, 1813-20, vol. 2, p. 380; and Gheschiedenissen, pp. 190, 395. For Hamey, see Keevil, op. cit., note 13 above, especially pp. 142-3; for Johannes Brovaert, see A. G. H. Bachrach, Sir Constantine Huygens and Britain 1596-1619, Leiden University Press, 1962, pp. 71, 120.

${ }^{33}$ Guildhall Library MS 7397/8, f. 192v. The consistory of Austin Friars, however, decided that the verger should first try the cheaper treatments available in the baths within the City before seeking cure at a water resort. This was not the first time the church paid for medical advice to one of its members. In 1612 the consistory had requested the Royal Surgeon, Christopher Frederick, a Dutchman, but not a member of the church, to provide medical advice for a certain Abraham Willemsen, see Guildhall Library MS 7397/7, f. 32r (22 October 1612). For Christopher Frederick, father of Sir John Frederick who became a member of Austin Friars, see A. T. Young, The Annals of the Barber-Surgeons of London, London, 1890, pp. 550-3.

${ }^{34}$ W. Birken, 'Dr John King (1614-1681) and Dr Assuerus Regemorter(1615-1650)', Med. Hist., 1976, 20: 276-95, pp. 292-3.
} 


\section{The Dutch response to plague in London}

And the rot did not stop there-for the first time one of the ministers failed the community during an epidemic. In May, Philip Op de Beck, the youngest of the congregation's three ministers, claimed that his health did not allow him to stay on in London. He pointed out to his colleagues that several doctors had advised him to go to the countryside to convalesce. The consistory accepted his excuses and released him temporarily from his duties. ${ }^{35}$ The other two ministers appear to have soldiered on until Cesar Calandrini, who had served the church since 1639 and who was by then close to 70 , informed the consistory on 21 September that one of his maids had caught the plague.

Mr Apothecary Upton, son of the plague-master, has her in hand and hopes to cure her. This is the reason why I have not been at the service for two days. I have separated my room and study from the sick room as far as my small house would allow me, and have taken a woman in the house to wait on me, who has not been near the invalid, whom my other servant has undertaken to nurse. I should have left the house if I had known where to go, not for fear of myself, but in order not to be prevented from our public services.

Calandrini was temporarily allowed to use the house of his colleague, Philip Op de Beck, while the latter "convalesced" in Barnes. Unfortunately Calandrini's move came too late. He died only five days later, on 26 September, having been ill for four days, and was buried the following day in the presence of a few leading members of the Dutch and French communities, since, as the minutes added, larger gatherings were prohibited by the City authorities "in this time of general infection of the plague". 36

Consequently the consistory found it necessary to request Op de Beck to return from Barnes to assist the minister, Jonas Proost. The church received a pathetic letter from Op de Beck, who claimed to suffer not only from "weakness in his head" but to have contracted a fever. This made it impossible for him to join the community in London, but in spite of his excuses, he was unable to hide his true motives.

Moreover, even if I were strong enough to discharge my duty, I should not dare to go so soon to my house from which our late brother Calendryn has been so recently carried away. Brother Proost writes that it is certain that brother Calandryn did not die of the plague; but it is difficult to be certain of this, as he wrote to me that his maidservant had the plague, and he went from his infected house into mine, in which he died after an illness of a few days. It is sufficiently known that in times of plague, all fevers are, to say the least, subject to suspicion so that brother Calandryn's fever might create an impression calculated to bring me and my family into difficulty. ${ }^{37}$

Conditions had, in other words, changed dramatically within the Dutch community in London between 1563 and 1665. A letter like Op de Beck's would never

\footnotetext{
${ }^{35}$ For Joas Evensen's letter, see Hessels, vol. 3, no. 3683. For Op de Beck, see Guildhall Library MS 7397/8, f. $272 \mathrm{v}$.

${ }^{36}$ Hessels, vol. 3, no. 3676; see also Guildhall Library MS 7397/8, f. 273v; for the plague-master, Nathaniel Upton, see Wilson, op. cit., note 1 above, p. 89.

${ }^{37}$ Hessels, vol. 3, no. 3680. The sum Austin Friars spent on poor relief during the plague of 1665 was smaller than in 1636. $£ 2,511$ was collected and $£ 2,279$ spent. The crisis inspired members to extra
} 


\section{Ole Peter Grell}

have been written in the Elizabethan period, when the religious zeal of the congregation's leaders would have excluded the possibility.

The Dutch community might have been "an example of foreign civility close to home" in 1563 , but by 1665 it had nothing of which to be proud. While the local authorities in London gradually managed to introduce some measure of improvement in the ways plague was tackled, in spite of all the difficulties presented by the population explosion, a decreasing Dutch community let an admirable system fall into decay before it finally folded in 1665 .

Two factors appear to have been at play. Firstly, the religious zeal and commitment of the founding fathers of Austin Friars was fading rapidly among their successors in the early Stuart period, when the effects of a growing secularization were making themselves felt. Secondly, in conjunction with this development, the community had become increasingly anglicized towards the middle of the seventeenth century. It was by then more than 60 years since the community had had a significant influx of new refugees from the Continent and most of its leaders belonged to either the first or the second generation born in England. During the 1640s an increasing number of members from the upper echelons of the congregation became active within local government rather than within the leadership of the church. This development is exemplified by the roles played by Alderman, Sir John Frederick and the Lord Mayor, Sir John Lawrence, during the great plague of 1665. At a time when most other people in authority had taken to their heels, both stayed in London throughout the epidemic and honoured their civic duties. It is significant for the change which had taken place within the congregation in Austin Friars, that in spite of both mens' membership of the church and their regular and generous contributions to collections, neither ever served the community as an elder or a deacon. This is even more remarkable when we bear in mind that both had married daughters of elders in Austin Friars. John Frederick married Mary, daughter of the merchant Thomas Rous, or Ruys, who served the Dutch church as a deacon from 1630 and as an elder from 1636; and John Lawrence, who was a nephew of the elder Adam Lawrence, married Abigail, daughter of the merchant Abraham van Ceulen, or Cullen, who served the congregation as a deacon from 1641 and then as an elder from $1653 .{ }^{38}$

contributions of over $£ 1,000$ as compared with the immediately preceding collections, for instance in 1664, when the deacons collected $£ 1,185$ and spent $£ 1,523$, see Guildhall Library MS 7408, under 1664 and 1665.

${ }^{38}$ Bell, op. cit., note 1 above, pp. 82-4, 277-8. For their membership of Austin Friars, see for instance Guildhall Library MS 7397/8, f. 255v (collection for the repair of the church in 1659; Alderman Jan Frederick $£ 5$ and Alderman Jan Laurens, jun., £5). John Frederick's engagement to Mary Ruys is registered in the minutes of Austin Friars in December 1636, see Guildhall Library MS 7397/8, f. 46r. Frederick was a lukewarm supporter of the Restoration and an anti-Court MP. He was worth $£ 2,000$ p.a. in 1660 and left $£ 42,000$ in his will. Lawrence married Abigail van Cuelen in 1643; Abraham van Cuelen became an elder in Austin Friars in 1653, see Hessels, vol. 3, no. 3241. Lawrence was also worth $£ 2,000$ p.a. and a leading City Whig. For both see J. R. Woodhead, The rulers of London 1660-1689. A biographical record of the Aldermen and Common Councilmen of the City of London, London, London \& Middlesex Archeological Society, 1966. There were, no doubt, a few exceptions to this picture of a community in decay. The Dutch church was still able to benefit from the dedicated service of at least one of its elders, the wealthy merchant Willem de Visscher, who had served the congregation from 1632, first as a deacon and then as an elder, see Grell, op. cit., note 10 above, p. 268. Visscher, however, was by then an unusual member of the church's consistory, being one of the few surviving leaders who had been born abroad. John Aubrey, who included Visscher in his Brief Lives, informs us that "he stayed in London during the whole time of the 
Before the Civil Wars, such powerful men would have felt obliged to serve the Dutch community as elders. After the Restoration they chose instead to serve the wider community in London. Their careers and civic leadership illustrate and emphasize that the Dutch community's loss eventually became London's gain.

Plague, and had all the time not one sick in his family. He was a temperate man, and had his house very cleanly kept", see Aubrey's Brief Lives, Harmondsworth, Penguin, 1978, pp. 466-7. It is interesting to see that Aubrey considered cleanliness, one of the standard attributes of the Dutch nation, a significant factor in explaining why Visscher and his household avoided catching the disease. Cleanliness among the Dutch does not, however, appear to have made any difference within the London community, which suffered as much as its English hosts. 